\title{
Cottage cheese fortified by natural additives
}

\author{
*Alibekov, R.S., Gabrilyants, E.A., Utebaeva, A.A., Nurseitova, Z.T., \\ Konarbayeva, Z.K. and Khamitova, B.M.
}

\section{Auezov'South-Kazakhstan University, 160000 Tauke Khan avenue, 5 Shymkent, Republic of Kazakhstan}

\section{Article history:}

Received: 11 April 2020

Received in revised form: 17 July 2020

Accepted: 20 February 2021

Available Online: 27

February 2021

\section{Keywords:}

Antioxidants,

Cottage cheese,

Ginger,

Topinambour,

Radish,

Vitamins

DOI:

https://doi.org/10.26656/fr.2017.5(S1).013

\begin{abstract}
Currently, a significant value for a correct nutrition and human metabolism has available the fermented milk products, as a cottage cheese that is produced by a culture of Lactis Lactococcus lactis subsp and Cremoris Lactococcus lactis subsp with pepsin. Moreover, the enrichment of the functional specificity of such products by vitamins C, E, A, D, K, macro - and microelements is a topical direction. The purpose of this study was to develop new cottage cheese compositions fortified by natural additives: ginger, topinambour and radish. For the achieving of it, following tasks were considered: creating of the cottage cheese production, sensory assessment, analyzing of the organoleptic and physicochemical characteristics, identifying of the macro- and microelements contents in the cottage cheese. From the available sources - ginger, topinambour and radish consist in following antioxidants: retinol (vitamin $A$ ), thiamine $\left(B_{1}\right)$, folacin $\left(B_{9}\right)$, riboflavin (vitamin $\mathrm{B}_{2}$ ), tocopherol (vitamin E), ascorbic acid (vitamin $\mathrm{C}$ ) and others. The organoleptic characteristics, such as: appearance and consistency, taste and smell, colour and physicochemical properties confirmed that the developed compositions meet the standard requirements for cottage cheese. Specifically, the samples had a milky-white color, a pleasant uniform consistency with additives particles, without odour and a moderate taste. In addition, the mineral content in the cottage cheese was determined by the Massspectrometry method and using the Scanning Electron Microscope. The presented samples have nutritional values and following valuable macro- and microelements: potassium $(15.43-26.90 \mathrm{mg} / \mathrm{kg})$, calcium $(6.83-14.37 \mathrm{mg} / \mathrm{kg})$, magnesium $(0.85-1.24 \mathrm{mg} / \mathrm{kg})$, phosphorus $97.91-21.77 \mathrm{mg} / \mathrm{kg}$ ), sodium $(3.25-7.36 \mathrm{mg} / \mathrm{kg}$ ) and others.
\end{abstract}

\section{Introduction}

Food fortification is one of the well-known public health interventions and one of the most effective methods of preventing nutritional deficiencies (Carbonera et al., 2020). Modification of fermented dairy products by introducing components of plant origin allows to set new functional properties for the traditional food products, and most importantly, to regulate the products chemical composition in accordance with modern requirements of the food science. Three basic components characterize consumer's behavior of the functional products: nutritional value, organoleptic properties and a directed physiological effect (Kantureeva et al., 2018). Dairy products with additives of antioxidant compounds have useful pharmacological characteristics and effective in the preventing a wide range of diseases (Shingisov and Alibekov, 2017; Tastemirova et al., 2019).
Existing technologies for the production of cottage cheese do not fully take into account physiological features of the human digestive systems that lead to a decrease in the effectiveness of their activities (Votincev et al., 2015; Gauri and Shiwangi, 2017).

Antioxidants are compounds that can delay or inhibit the oxidation of lipids or other molecules by inhibiting the initiation or propagation of oxidizing chain reactions (Shingisov et al., 2016; Zheleuova et al., 2021). In general, there are two basic categories of antioxidants: natural and synthetic (Alibekov et al., 2017; Ivanova et al., 2020). Recently, interest has increased considerably in finding naturally occurring antioxidants for use in foods or medicinal materials to replace synthetic antioxidants that are being restricted due to their carcinogenicity (Alibekov et al., 2019; Satayev et al., 2015). The main sources of natural antioxidants for humans are raw fruits and vegetables (Alibekov et al., 
2020).

Ginger, topinambour and radish are well-known vegetables that have antioxidant and unique useful nutritional properties. Ginger (Zingiber officinale) is an aromatic plant, has antimicrobial, antioxidant, antiinflammatory, anticoagulant, analgesic, carminative and tonic actions, improves immunity and protects the human body from parasites that is used in the food industry, medicine and cosmetology. As part of ginger are: ascorbic acid (vitamin $\mathrm{C}$ ), thiamine $\left(\mathrm{B}_{1}\right)$, riboflavin (vitamin $\mathrm{B}_{2}$ ), tocopherol (vitamin $\mathrm{E}$ ), essential amino acids and essential oils. Essential oils and ginger oleoresin (Zingiber officianale R.) have the prolong antioxidant properties (Prakash, 2010; Beristain-Bauza et al., 2019). Moreover, at higher concentrations, red ginger shows antimicrobial and antifungal characteristics (Widayat et al., 2020).

Mostly, ginger rhizome and its callus have a potential source of phenolics with antioxidant activity. 6gingerol and 6-shogaol displayed comparable antioxidant capacity and activity (Ali et al., 2018; Idris et al., 2019).

The topinambour (Jerusalem artichoke) is an agricultural crop which is of great potential for food, production of fuels, and industrial products. This crop gives a high yield in tubers, it grows better in poor soils than most crops, and it is resistant to pests and common plant diseases as well as to cold temperatures (Kosaric et al., 1984).

Topinambour (Jerusalem artichoke) is used to diminish the potential risk of a number of diseases, such as gout, diabetes, gastric ulcer, obesity, coronary heart disease and others. Useful properties and availability of topinambour make it promising widespread use in the food industry. Inulin is a part of topinambour, a prebiotic and natural sugar substitute (Manzoni et al., 1992).

Topinambour also contains thiamine $\left(\mathrm{B}_{1}\right)$, ascorbic acid (vitamin C), and many useful microelements (Conde et al., 1991). The topinambour tubercles are rich in polysaccharides: cellulose, hemicellulose, pectin and polyfructosane (El Yachioui et al., 1994).

Radish (Raphanus raphanistrum subsp. Sativus) is recognized as the root vegetable was used for the human diet all over the world (Lim et al., 2019). The enlarged root and hypocotyl of radish are consumed mainly as a salted vegetable and are also eaten fresh as grated radish, garnish, and salad (Kaneko and Matsuzawa, 1993).

Radish has antimicrobial, stimulating function of the digestive glands, anti-sclerotic and antiseptic healing properties. It is used in the treatment of radiculitis, liver, intestines, kidneys, gall bladder, digestive organs, etc. Radish consists in: folacin (B9), ascorbic acid (vitamin $\mathrm{C})$, vitamin $\mathrm{K}$ and many useful microelements (Jayakumar et al., 2007). In this regard, the study aimed to develop of new cottage cheese fortified by natural additives from ginger, topinambour and radish.

\section{Materials and methods}

In the creation of new food product, it is important to know a nutritional value of the used additives. Such data allow for the predicting of the best compatibility of substances in the product, as well as organoleptic properties. In the present work, one of the main criteria for the selection of plant origin supplements was a yellow-white color that specific for the natural cottage cheese.

\subsection{Raw materials}

Basically, standard generally known and modified research methods of raw materials and final products were applied. The following raw materials were used:

- Cow milk that accepted in accordance with the GOST 31449-2013 (Federal Agency for Technical Regulation and Metrology, 2013);

- Enzyme milk-clotting according to the GOST R52688 (Federal Agency for Technical Regulation and Metrology, 2008), particularly starter that consists of: Lactis Lactococcus lactis subsp and Cremoris Lactococcus lactis subsp;

- Calcium chloride according to the COST 559732014 (Federal Agency for Technical Regulation and Metrology, 2015);

- Extracts from plant raw materials according to the ST RK 978-2001 (Federal Agency for Technical Regulation and Metrology, 2001).

\subsection{Extraction of natural additives using supercritical carbon dioxide extraction}

The natural additives were extracted using the supercritical carbon dioxide extraction. Carbon dioxide compressed under very high pressure; a desired ingredient released from the above mentioned plant material. With a decrease in pressure, carbon dioxide gave up dissolved substances and an extract obtained. Particularly, supercritical fluid carbon dioxide had properties between a gas and a liquid that improved a biological value and original properties of the extract.

Ginger, topinambour and radish purchase from the local market was crushed and loaded into the extractor. Following the settings of the pressure $(62$ bar) and 
temperature parameters $\left(23-24^{\circ} \mathrm{C}\right)$ of the technological process, liquefied carbon dioxide was pumped from the storage tank to the extractor vessel using a high-pressure pump. The stream of carbon dioxide with the substances in the extractor entered the collector. At the successive depressurization, carbon dioxide vaporized, and the extract was deposited in the collector. The extraction process took $4 \mathrm{hrs}$ which yielded $1.0-3.0 \%$ extract (Federal Agency for Technical Regulation and Metrology, 2001).

\subsection{Cottage cheese production}

Cottage cheese (tvorog in Russian) is a fermented milk product that produced by using starter microorganisms - Lactococci or a mixture of Lactococci and Thermophilic lactic streptococci and acid or acidrennet coagulation of proteins with subsequent removal of serum by self-pressing and (or) pressing (Federal Agency for Technical Regulation and Metrology, 2014).

It was used the acid-rennet method of milk coagulation, where the clot is formed by the combined action of rennet and lactic acid. Casein during a transition to the paracasein shifts the isoelectric point from $\mathrm{pH} 4.6$ to 5.2. In this regard, the formation of a clot under the action of rennet enzyme occurs faster, at a lower acidity, than proteins are deposited with lactic acid. The resulting clot should have a lower acidity, and the technological process normally is achieved during 24 hours.

For the cottage cheese production, raw milk was accepted. Then, the milk was normalized to the required composition. The milk was cleaned and pasteurized at 78 $-80^{\circ} \mathrm{C}$ within 20 to $30 \mathrm{~s}$. The milk was cooled until the fermentation temperature at $30-32^{\circ} \mathrm{C}$. Next, starter was introduced into the milk followed by $40 \%$ calcium chloride liquid to coagulate the milk. After the milk is coagulated, $20 \%$ of the rennet liquid was introduced. The clot is then cut, heated and treated. The serum was separated. The prepared plant extracts were added and mixed. The clot was allowed to cool and the pasteurization was done at $78-80^{\circ} \mathrm{C}$ within 20 to $30 \mathrm{~s}$. The pasteurized clot was packaged.

\subsection{Sensory assessment}

For an extended study of the organoleptic characteristics of cottage cheese with additives, the sensory analysis to evaluate the food products in scores. The set of numerical values, combining the assessment of the properties of the analyzed food product in a given quality range, forms a point scale. The advantages of this method include its large informational capabilities due to the use of multiple point scales and their modifications.
By using a five-point scale, color, smell, taste, texture was evaluated. The products color was determined by taking into account the absence of extraneous shades. In the determining of taste and smell, a main attention is paid to the purity of smell, an absence of extraneous tastes and odors, as well as how clearly the taste is flavored. The consistency was determined by filling the samples into an experimental glass.

In the universal system, four levels of positive quality are sufficient and the fifth is an unsatisfactory rating. These requirements are met by a five-point scale in which estimates are provided with integers: 5 excellent quality (80-100\%), 4 - above average (60$80 \%), 3$ - average or satisfactory $(40-60 \%), 2$ unsatisfactory $(20-40 \%), 1$ - very poor or unacceptable (0- 20\%).

\subsection{Organoleptic characteristics}

Organoleptic characteristics including appearance and consistency, taste and smell, colour were analyzed in accordance with the GOST 31453-2013 (Federal Agency for Technical Regulation and Metrology, 2014).

\subsection{Physicochemical characteristics}

Physicochemical indicators of cottage cheese: mass fractions of fats, mass fraction of water, acidity, mass fraction of proteins was identified in accordance with the GOST 31453-2013 (Federal Agency for Technical Regulation and Metrology, 2014).

\subsection{Macro- and microelements contents in the cottage cheese}

The content of mineral substances in cottage cheese was determined by the method of Mass-spectrometry with inductively coupled plasma (ICP-MS) and using a Scanning Electron Microscope (SEM). The method of mass-spectrometry with inductively coupled plasma (ICP -MS) allows defining a number of metals and several non-metals at concentrations up to $10^{-10} \%$, i.e., one particle of $10^{12}$, with the atomic mass from 7 to 250 , i.e. from $\mathrm{Li}$ to $\mathrm{U}$ elements. It is able to determine the content of nanograms per liter to 10 to $100 \mathrm{mg} / \mathrm{L}$. The method is based on using of the inductive-connected plasma, as a source of ions and mass spectrometer for their separation and detection in an argon atmosphere. Unlike atomic absorption spectroscopy, defining only one element, ICP -MS can identify all elements simultaneously, which allows to considerably speed up the process of measurement (Thompson and Wolsh, 1988; Alibekov et al., 2020).

Preparation of ash samples for the analysis of the chemical composition were performed according to the 
GOST 26929-94 (Federal Agency for Technical Regulation and Metrology, 1994). The method of dry mineralization was based on full decomposition of organic substances by combustion of the sample in an electric stove at a controlled temperature of $450-500^{\circ} \mathrm{C}$ (Thompson and Wolsh, 1988).

\section{Results and discussion}

\subsection{Organoleptic characteristics of extracts}

Aqueous extracts of ginger, topinambour and radish were used as plant supplements with antioxidant properties. At first, the organoleptic properties were analyzed. Mostly, appearance and consistency for all three types of extracts had homogeneous liquid without sediment. For ginder extract, it was characterized a slightly burning taste and smell. Respectively for topinambour and radish were slightly sweet and specific flavors. Regarding colour, following characteristics were available: darkly yellow-brown for ginger, slightly yellow-brown for topinambour and brightly white for radish.

As can be seen, ginger has more specific organoleptic characteristics than topinambour and radish. However, after pouring of these extracts into the cottage cheese mass, such properties, as colour, taste and smell have allowable capabilities that permit to use in the production of fermented milk products.

\subsection{Sensory assessment}

It was determined that the quantitative content of the additive is significantly affects to the organoleptic characteristics and specifically for a sensory assessment of the final food product. The content of extracts from three kinds of plants varied from $1 \%$ to $10 \%$ of the total volume of the cottage cheese product (Figures 1 - 3).

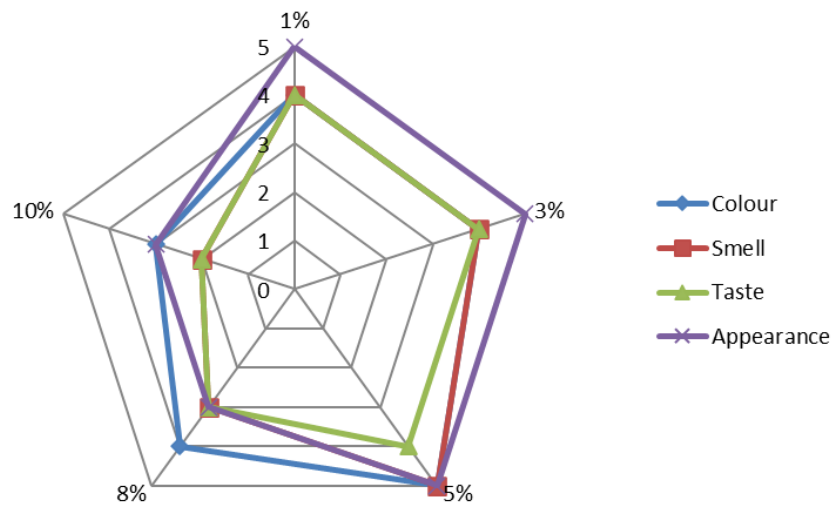

Figure 1. Sensory assessment of the cottage cheese with the addition of ginger extract, in scores

It should be noted, a highest sensory assessment was obtained for the samples with a content of $3-5 \%$ of extracts of ginger, topinambour and radish. These samples had a milky-white color, a pleasant uniform consistency with additives particles, without outside odors and a moderately taste of ginger, topinambour and radish. Samples in which the filler content was $8-10 \%$ had the lowest organoleptic characteristics, because there was a thick consistency with a strong specific taste of the filler. In this regard, for a further study, the samples with the addition of $5 \%$ extracts of ginger, topinambour and radish were taken into account.

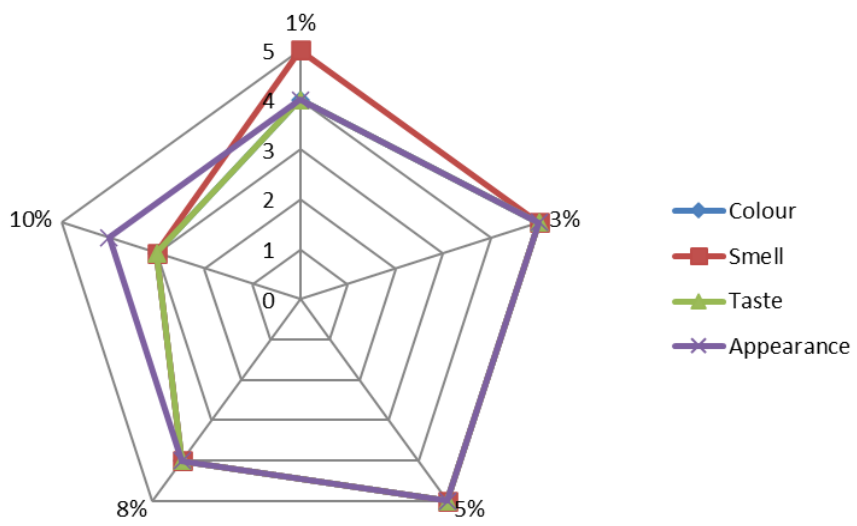

Figure 2. Sensory assessment of cottage cheese with the addition of topinambour extract, in scores

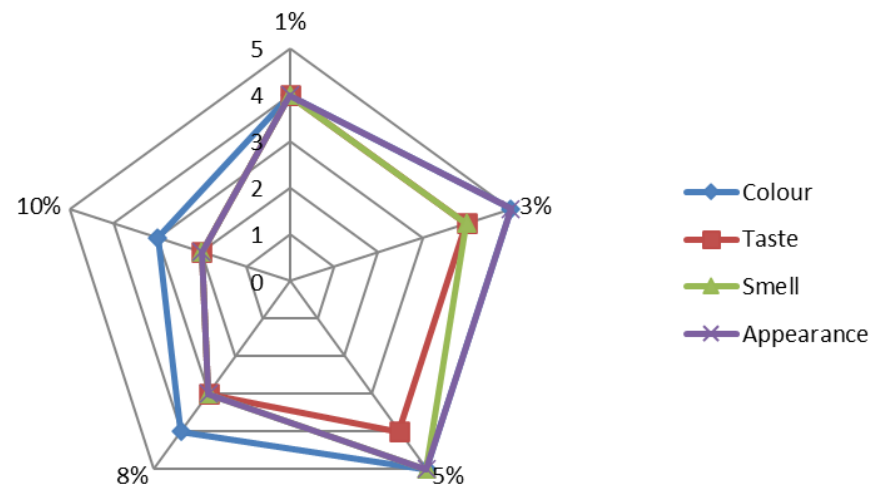

Figure 3. Sensory assessment of the cottage cheese with the addition of radish extract, in scores

\subsection{Organoleptic characteristics}

Comparison of the organoleptic characteristics of the obtained samples with the requirements of GOST 314532013 (Federal Agency for Technical Regulation and Metrology, 2014) for the cottage cheese is presented in Table 1.

Analysis of the results of the organoleptic evaluation of cottage cheese, produced using extracts of ginger, topinambour and radish, testifies for the originality of the finished product. Taste, smell, colour, appearance and consistency fully meet the requirements for a cottage cheese.

\subsection{Physicochemical characteristics}

As well the comparison of the physicochemical parameters of the cottage cheese with and without extracts of natural origin was done (Table 2). 
Table 1. Organoleptic characteristics of cottage cheese

\begin{tabular}{|c|c|c|c|c|c|}
\hline \multirow[b]{2}{*}{$\begin{array}{l}\text { Name of } \\
\text { the } \\
\text { indicator }\end{array}$} & \multirow[b]{2}{*}{ GOST 31453-2013 } & \multicolumn{4}{|c|}{ Cottage cheese } \\
\hline & & $\begin{array}{c}\text { Control sample } \\
\text { without } \\
\text { additives }\end{array}$ & $\begin{array}{l}\text { Sample with } \\
\text { ginger extract }\end{array}$ & $\begin{array}{c}\text { Sample with } \\
\text { topinambour } \\
\text { extract }\end{array}$ & $\begin{array}{l}\text { Sample with } \\
\text { radish extract }\end{array}$ \\
\hline $\begin{array}{l}\text { Appearance } \\
\text { and } \\
\text { consistency }\end{array}$ & $\begin{array}{l}\text { Soft smearing or crumbly mass } \\
\text { with or without tangible milk } \\
\text { protein particles. For a fat-free } \\
\text { product - a slight release of serum. } \\
\text { Pure, dairy, without foreign tastes } \\
\text { and odors. For product from } \\
\text { reconstituted with a taste of } \\
\text { powdered milk. }\end{array}$ & $\begin{array}{l}\text { Cottage cheese } \\
\text { grains with soft } \\
\text { smearing } \\
\text { consistency }\end{array}$ & $\begin{array}{l}\text { Soft cottage } \\
\text { cheese grains, } \\
\text { easily smeared } \\
\text { consistency }\end{array}$ & $\begin{array}{l}\text { Soft cottage } \\
\text { cheese grains, } \\
\text { easily smeared } \\
\text { consistency }\end{array}$ & $\begin{array}{l}\text { Soft cottage } \\
\text { cheese grains, } \\
\text { easily smeared } \\
\text { consistency }\end{array}$ \\
\hline $\begin{array}{l}\text { Taste and } \\
\text { smell }\end{array}$ & $\begin{array}{l}\text { Pure, dairy, without foreign tastes } \\
\text { and odors. For product from } \\
\text { reconstituted with a taste of } \\
\text { powdered milk. }\end{array}$ & $\begin{array}{l}\text { Pure, dairy, } \\
\text { without foreign } \\
\text { tasters and } \\
\text { odors }\end{array}$ & $\begin{array}{l}\text { Pure, dairy with } \\
\text { a burning taste } \\
\text { of ginger, no } \\
\text { odor }\end{array}$ & $\begin{array}{l}\text { Pure, dairy with } \\
\text { a sweetish taste } \\
\text { and smell of } \\
\text { Jerusalem } \\
\text { artichoke }\end{array}$ & $\begin{array}{l}\text { Pure, fermented } \\
\text { milk with a } \\
\text { distinct taste } \\
\text { and specific } \\
\text { smell of radish }\end{array}$ \\
\hline Colour & $\begin{array}{l}\text { White with a cream shade, uniform } \\
\text { throughout the mass. }\end{array}$ & $\begin{array}{c}\text { White with a } \\
\text { yellow-milky } \\
\text { shade }\end{array}$ & $\begin{array}{l}\text { White, with a } \\
\text { significant } \\
\text { amount of } \\
\text { splashes of a } \\
\text { yellow-milky } \\
\text { tint }\end{array}$ & $\begin{array}{l}\text { White, with a } \\
\text { yellow-milky } \\
\text { tint }\end{array}$ & $\begin{array}{c}\text { White with a } \\
\text { yellow-greenish } \\
\text { tint }\end{array}$ \\
\hline
\end{tabular}

Table 2. Physicochemical indicators of cottage cheese

\begin{tabular}{|c|c|c|c|c|c|}
\hline \multirow[b]{2}{*}{ Name of the indicator } & \multirow[b]{2}{*}{$\begin{array}{l}\text { GOST 31453- } \\
\quad 2013\end{array}$} & \multicolumn{4}{|c|}{ Cottage cheese } \\
\hline & & $\begin{array}{c}\text { Control sample } \\
\text { without additives }\end{array}$ & $\begin{array}{l}\text { Sample with } \\
\text { ginger extract }\end{array}$ & $\begin{array}{c}\text { Sample with } \\
\text { topinambour extract }\end{array}$ & $\begin{array}{l}\text { Sample with } \\
\text { radish extract }\end{array}$ \\
\hline $\begin{array}{l}\text { Mass fraction of fats, } \% \text {, not } \\
\text { less }\end{array}$ & $4.0-9.0 \%$ & $5.0 \%$ & $5.0 \%$ & $8.0 \%$ & $9.0 \%$ \\
\hline $\begin{array}{l}\text { Mass fraction of moisture, } \% \text {, } \\
\text { not more }\end{array}$ & $75.0 \%$ & $60.0 \%$ & $65.0 \%$ & $65.0 \%$ & $60.0 \%$ \\
\hline Acidity, ${ }^{\circ} \mathrm{T}$, not more & $220^{\circ} \mathrm{T}$ & $180^{\circ} \mathrm{T}$ & $200^{\circ} \mathrm{T}$ & $180^{\circ} \mathrm{T}$ & $150^{\circ} \mathrm{T}$ \\
\hline $\begin{array}{l}\text { Mass fraction of proteins, } \% \text {, } \\
\text { not less }\end{array}$ & $16.0 \%$ & $16.0 \%$ & $16.0 \%$ & $16.0 \%$ & $20.0 \%$ \\
\hline
\end{tabular}

The level of mass fraction of fat in the studied samples was between 5.0-9.0\%. These values satisfy the GOST 31453-2013 requirements (Federal Agency for Technical Regulation and Metrology, 2014), when a fat content should be within 4.0-9.0\%. Mass fraction of moisture for all samples was among 60-65\%; acidity was $150-200^{\circ} \mathrm{T}$; and mass fraction of proteins was $16-20 \%$. The values of the mass fraction of moisture, acidity and mass fraction of protein were within acceptable limits. The experimental data are fully meet the requirements for the cottage cheese.

\subsection{Macro- and microelements contents in the cottage cheese}

The compositions of macro- and microelements of the investigated cottage cheese samples by using ICPMS have the following data (Table 3; Figures 4 - 7).

The comparative analysis of the macro- and microelements contents of the samples versus control sample containing the cottage cheese without additives showed the presence of valuable macro- and microelements: potassium, calcium, magnesium, phosphorus, sodium and other. However, it should be noted for the samples with additives, these data are significantly increased that showed of the nutritional values of the researched dairy products.

\section{Conclusion}

The use of natural ingredients such as ginger, topinambour and radish that have antioxidant properties, in cottage cheese compositions, allows for the developing of new enriched fermented milk products. From available data, ginger, topinambour and radish consist in the following antioxidants: retinol (Vitamin $\mathrm{A})$, thiamine $\left(\mathrm{B}_{1}\right)$, folacin (B9), riboflavin (vitamin $\mathrm{B}_{2}$ ), tocopherol (vitamin $\mathrm{E}$ ), ascorbic acid (vitamin $\mathrm{C}$ ), essential amino acids and many useful macro- and microelements. As can be seen, highest sensory assessments were obtained for the samples with a content of $3-5 \%$ of extracts of ginger, topinambour and radish. These samples had a milky-white color, a pleasant uniform consistency with additives particles, without outside smells and a moderately taste of ginger, 
Table 3. Content of chemical elements in the cottage cheese ashes

\begin{tabular}{ccccc}
\hline \multirow{2}{*}{ Name of element } & \multicolumn{4}{c}{ Samples, mass, in mg/kg } \\
\cline { 2 - 5 } & $\begin{array}{c}\text { Control sample } \\
\text { without additives }\end{array}$ & $\begin{array}{c}\text { Sample with ginger } \\
\text { extract }\end{array}$ & $\begin{array}{c}\text { Sample with } \\
\text { topinambour extract }\end{array}$ & $\begin{array}{c}\text { Sample with radish } \\
\text { extract }\end{array}$ \\
\hline Sodium & 1.89 & 3.25 & 5.84 & 7.36 \\
Magnesium & 0.47 & 1.01 & 1.24 & 0.85 \\
Phosphorus & 10.56 & 21.17 & 8.22 & 7.91 \\
Sulphur & 0.23 & 0.22 & 0.72 & 0.42 \\
Chlorine & 0.59 & 1.09 & 15.48 & 19.33 \\
Potassium & 8.77 & 15.43 & 26.90 & 18.84 \\
Calcium & 8.21 & 14.37 & 6.83 & 10.98 \\
\hline
\end{tabular}

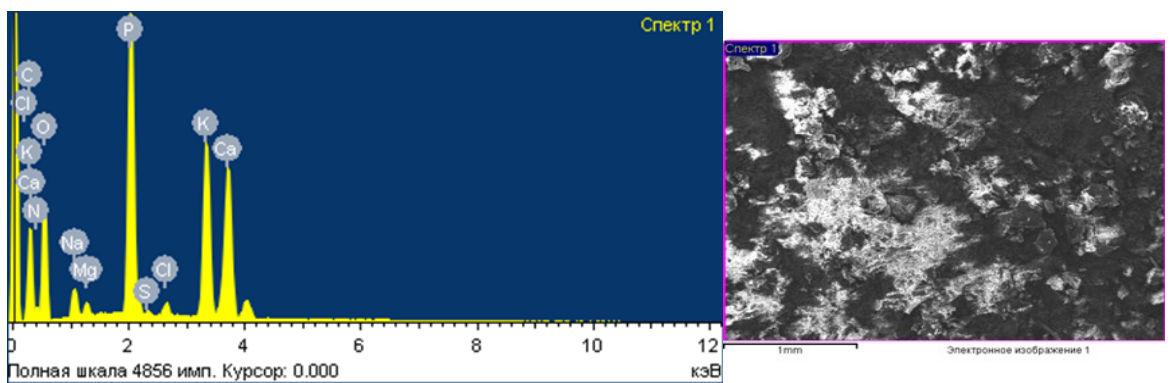

Figure 4. ICP-MS of compound number 1

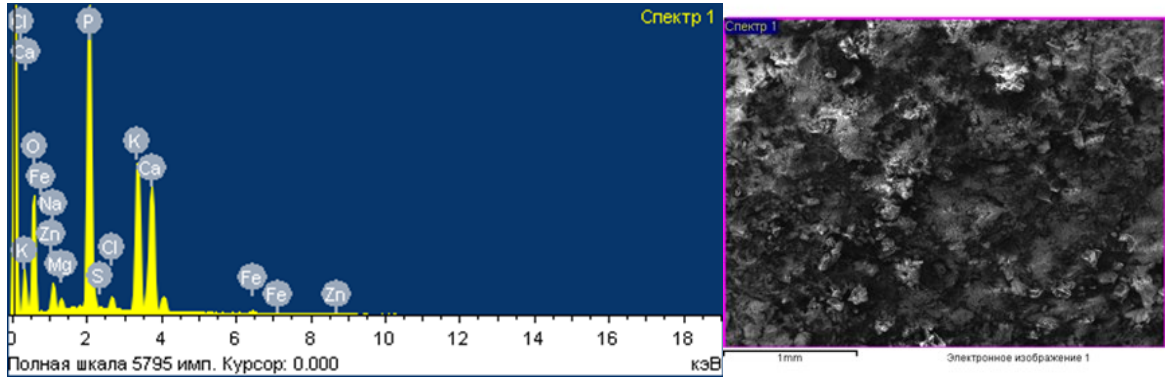

Figure 5. ICP-MS of compound number 2

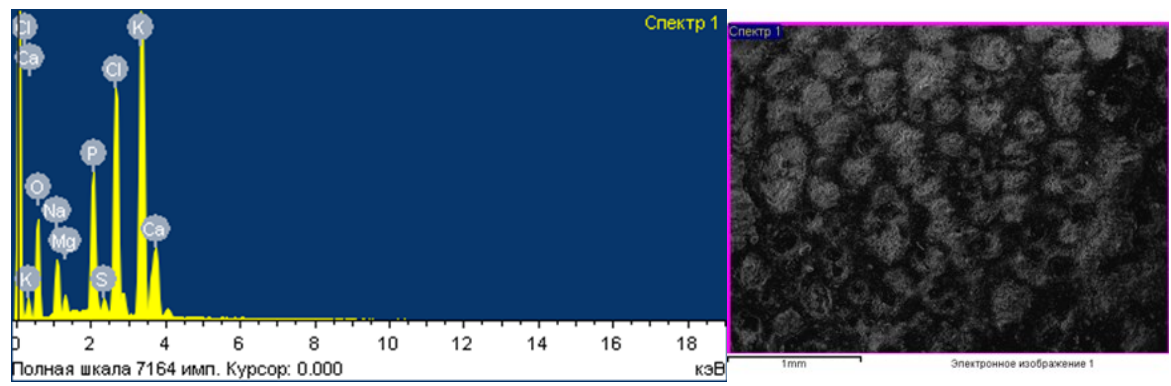

Figure 6. ICP-MS of compound number 3

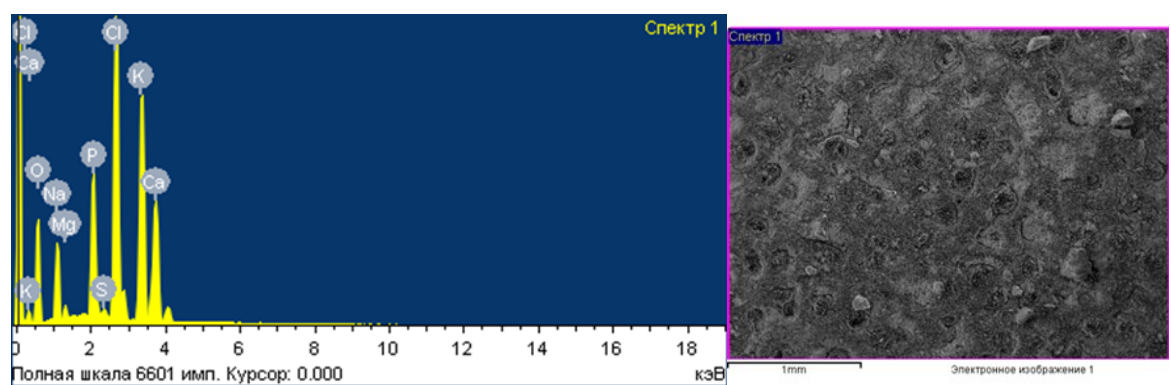

Figure 7. ICP-MS of compound number 4

topinambour and radish. Organoleptic properties, sensory assessment and physicochemical parameters confirm that the developed compositions satisfy to the GOST standard requirements for a cottage cheese. The content of mineral substances in the cottage cheese was determined by the method of Mass-spectrometry with inductively coupled plasma (ICP-MS) and by using a Scanning Electron Microscope (SEM). The analyzed samples have nutritional values and essential macro- and microelements: potassium, calcium, magnesium, phosphorus, sodium and others. 


\section{References}

Ali, A.M.A., El-Nour, M.E.M. and Yagi, S.M. (2018). Total phenolic and flavonoid contents and antioxidant activity of ginger (Zingiber officinale Rosc.) rhizome, callus and callus treated with some elicitors. Journal of Genetic Engineering and Biotechnology, 16(2), 677-682. http:// doi.org/10.1016/j.jgeb.2018.03.003

Alibekov, R.S., Kaiypova, A.B., Urazbayeva, K.A., Ortayev, A.E. and Azimov, A.M. (2019). Effect of substitution of sugar by high fructose corn syrup of the confiture on the base of Physalis. Periodico Tche Quimica, 16(32), 688-697.

Alibekov, R.S., Kenzhibayeva, G.S., Utebaeva, A.A., Urazbayeva, K.A., Tursynbay, L.M. and Kulanova, D.A. (2020). Enriched plum filling for the confectionery. Food Research, 4(6), 26-34. https:// doi.org/10.26656/fr.2017.4(S6).014

Alibekov, R.S., Sikorski, M., Urazbayeva, K.A. and Gabrilyants, E.A. (2017). Physico-chemical study of macro-and microelement composition of the enriched macaroni products. News of the National Academy of Sciences of the Republic of Kazakhstan, Series Chemistry and Technology, 3(423), 13-20.

Beristain-Bauza, S.D.C., Hernández-Carranza, P., CidPérez, T.S., Ávila-Sosa, R., Ruiz-López, I.I. and Ochoa-Velasco, C.E. (2019). Antimicrobial activity of ginger (Zingiber Officinale) and its application in food products. Food Reviews International, 35(5), 407-426.

doi.org/10.1080/87559129.2019.1573829

Carbonera, A.F.A., Tayobong, R.R.P., Barrameda, L.I.C. and Miranda, A.M.V. (2020). Nutritional and functional properties of dried Momordica cochinchinensis Spreng. fruit aril and its application in cheese spread production. Food Research, 4(6), 1947 - 1953. https://doi.org/10.26656/fr.2017.4 (6). 221

Conde, J.R., Tenorio, J.L., Rodriguez-Maribona, B. and Ayerbet, L. (1991). Tuber yield of Jerusalem artichoke (Helianthus tuberosus L.) in relation to water stress. Biomass and Bioenergy, 1(3), 137-142. https://doi.org/10.1016/0961-9534(91)90022-5

El Yachioui, M., El Halloui, N. and Villa, R. (1994). Valorisation des tubercules de topinambour par hydrolyse enzymatique. Journal of Food Engineering, 23(1), 1-19. https:// doi.org/10.1016/0260-8774(94)90120-1

Federal Agency for Technical Regulation and Metrology (1994). Raw material and food-stuffs. Preparation of samples. Decomposition of organic matters for analysis of toxic elements. (GOST 26929-94).
Retrieved

from

http://docs.cntd.ru/ document/1200021120. [In Russian].

Federal Agency for Technical Regulation and Metrology (2001) Extracts from plant materials. Technical requirements (ST RK 978-2001). Retrieved from http://www.vniiki.ru/document/5295883.aspx. [In Russian].

Federal Agency for Technical Regulation and Metrology (2008). Enzyme milk-clotting of animal origin dry. Specifications (GOST R52688). Retrieved from http://docs.cntd.ru/document/gost-r-52688-2006. [In Russian].

Federal Agency for Technical Regulation and Metrology (2014). Cottage cheese (Tvorog) Specifications (GOST 31453-2013). Retrieved from http:// docs.cntd.ru/document/1200102733. [In Russian].

Federal Agency for Technical Regulation and Metrology (2013). Raw cow's milk Specifications (GOST 31449-2013). Retrieved from http://docs.cntd.ru/ document/1200102731. [In Russian].

Federal Agency for Technical Regulation and Metrology (2015). Food additives. Calcium chloride. Technical requirements (GOST 55973-2014). Retrieved from http://docs.cntd.ru/document/1200109406.

Russian].

Gauri, A. and Shiwangi, M. (2017). Immobilization and microencapsulation. Journal of Advanced Research in Biotechnology, 2(3), 1-4. https:// doi.org/10.15226/2475-4714/2/3/00129

Idris, N.A., Yasin, H.M. and Usman, A. (2019). Voltammetric and spectroscopic determination of polyphenols and antioxidants in ginger (Zingiber officinale Roscoe). Heliyon, 5(5), e01717. https:// doi.org/10.1016/j.heliyon.2019.e01717

Ivanova, M., Balabanova, T., Kostov, G. and Uzunova, G. (2020). Comparative study on different incorporation of olive oil and dill extract in fresh cheese. Food Research, 4(6), 2233 - 2240. https:// doi.org/10.26656/fr.2017.4(6).341

Jayakumar, K., Jaleel, C.A. and Vijayarengan, P. (2007). Changes in growth, biochemical constituents and antioxidant potentials in radish (Raphanus sativus L.) under cobalt stress. Turkish Journal of Biology, 31(3), 127-136.

Kantureeva, G.O., Defrancesco, E., Alibekov, R.S., Urazbayeva, K.A. and Efimova, I.E. (2018). New trends in the identification of the traditional food products of Kazakhstan. News of the National Academy of Sciences of the Republic of Kazakhstan, Series Chemistry and Technology 5(431): 13-20. https://doi.org/10.32014/2018.2518-1491.1

Kaneko, Y. and Matsuzawa, Y. (1993). Radish: 
Raphanus sativus L. In Kalloo, G. and Bergh, B.O. Genetic Improvement of Vegetable Crops, p. 487510. USA: Elsevier. https://doi.org/10.1016/B978-008-040826-2.50039-4

Kosaric, N., Cosentino, G.P., Wieczorek, A. and Duvnjak, Z. (1984). The Jerusalem artichoke as an agricultural crop. Biomass, 5(1), 1-36. https:// doi.org/10.1016/0144-4565(84)90066-0

Lim, H.W., Song, K.Y., Chon, J.W., Jeong, D. and Seo, K.H. (2019). Organoleptic characteristics of dairy products supplemented with Raphanus raphanistrum subsp. sativus (radish) powder: a preliminary study on efficacy against diabetes. Journal of Milk Science and Biotechnology, 37(3), 177-186. https:// doi.org/10.22424/jmsb.2019.37.3.177

Manzoni, M. and Cavazzoni, V. (1992). Hydrolysis of topinambur (Jerusalem artichoke) fructans by extracellular inulinase of Kluyveromyces marxianus var. bulgaricus. Journal of Chemical Technology and Biotechnology, 54(4), 311-315. https:// doi.org/10.1002/jctb.280540402

Prakash, J. (2010). Chemical composition and antioxidant properties of ginger root (Zingiber officinale). Journal of Medicinal Plants Research, 4, 2674-2679. https://doi.org/10.5897/JMPR09.464

Satayev, M.I., Alibekov, R.S., Satayeva, L.M., Baiysbay, O.P. and Mutaliyeva, B.Z. (2015). Characteristics of activated carbons prepared from apricot kernel shells by mechanical, chemical and thermal activations. Modern Applied Science, 9(6), 104-119. h https:// doi.org/10.5539/mas.v9n6p104

Shingisov, A.U. and Alibekov, R.S. (2017). Analyse of the moisture evaporation process during vacuum freeze-drying of koumiss and shubat. Heat and Mass Transfer, 53(5), 1571-1578.

Shingisov, A.U., Alibekov, R.S., Myrkalykov, B.S., Musayeva, S.A., Urazbayeva, K.A. and Iskakova, S.K. (2016). Physicochemical Characteristics of the New Polyphyto-Component Composition for Food Industry. Biosciences Biotechnology Research Asia, 13(2), 879-886. https://doi.org/10.13005/bbra/2110

Tastemirova, U.U., Alibekov, R.S. Ciprovica, I., Shingisov, A.U., Mukhtarkhanova, R.B. and Mailybaeva, E.U. (2019). The optimal freezing temperature of cow milk and camel milk. News of the National Academy of Sciences of the Republic of Kazakhstan, Series Chemistry and Technology, 3 (435), 19-24. https://doi.org/10.32014/2019.25181491.24

Thompson, M.M. and Wolsh, D.N. (1988). Guideline for spectrometric analysis with inductive-bonded plasma, p. 288. Moscow, Nedra.
Widayat, Satriadi, H., Cahyono, B., Girsang, D., Prabandari, N. and Dita, A.S. (2020). The characterization of physicochemical, microbiological and sensorial red ginger yogurt during fermentation. Food Research, 4(5), 1753 - 1757. https:// doi.org/10.26656/fr.2017.4(5).127

Zheleuova, Z.S., Uzakov, Y.M., Shingisov, A.U., Alibekov, R.S. and Khamitova, B.M. (2021). Development of halal cooked smoked beef and turkey sausage using a combined plant extracts. Journal of Food Processing and Preservation, 45(1), e15028. https://doi.org/10.1111/ jfpp. 15028 